\title{
Supporting information for: Structural Modifications Controlling Membrane Raft Partitioning and Curvature in Human and Viral Proteins
}

Deniz Yurtsever ${ }^{1}$ and Joseph Helmuth Lorent ${ }^{2, *}$

${ }^{1}$ Theoretical Biology and Bioinformatics, Department of Biology, Utrecht University, Padualaan 8, NL$3584 \mathrm{CH}$ Utrecht, The Netherlands

${ }^{2}$ Membrane Biochemistry \& Biophysics, Bijvoet Center for Biomolecular Research, Department of Chemistry, Utrecht University, Padualaan 8, NL-3584CH Utrecht, The Netherlands

*Corresponding author, j.h.f.f.lorent@uu.nl, Phone: +31302533966 

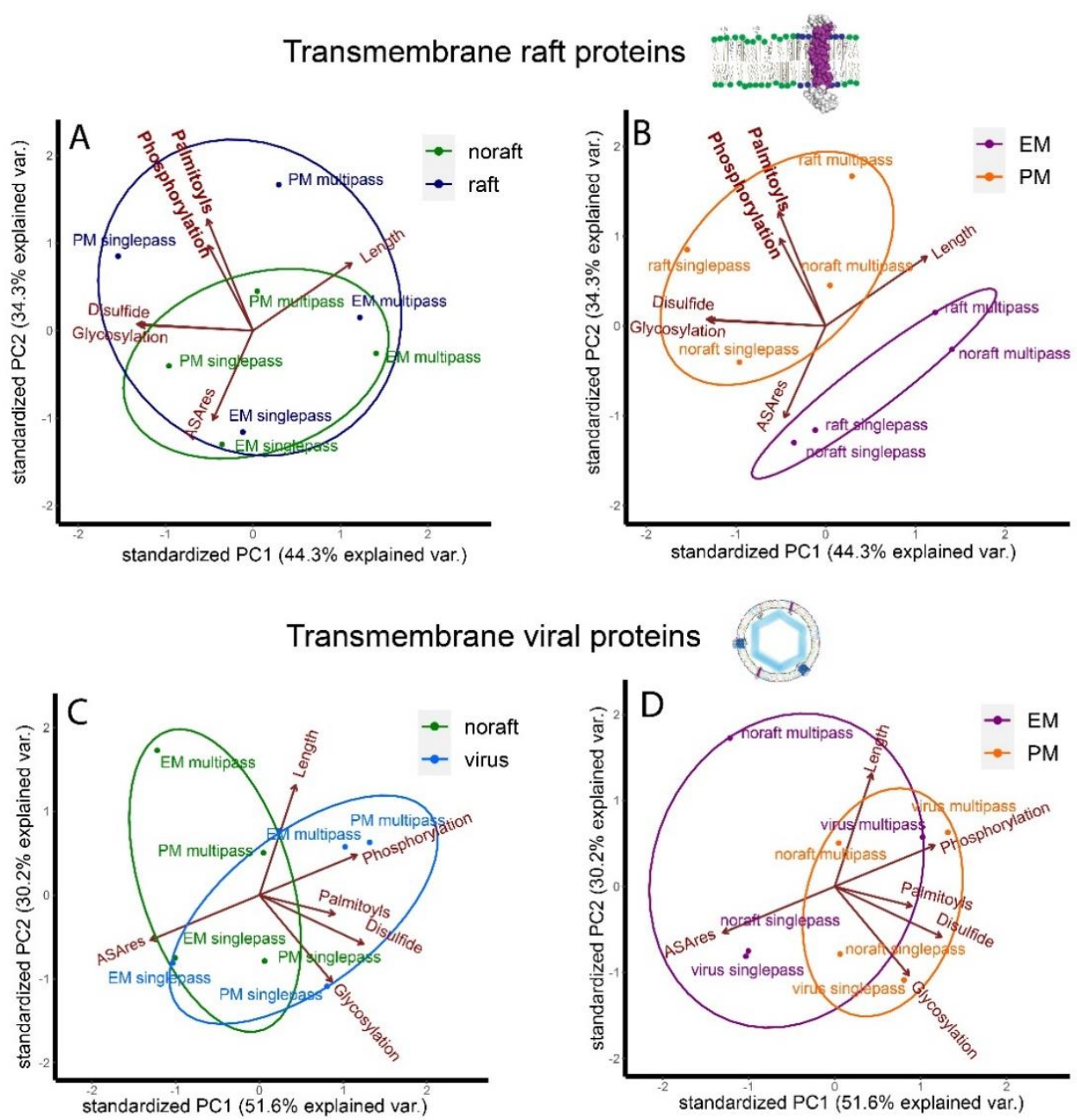

\section{iral proteins}
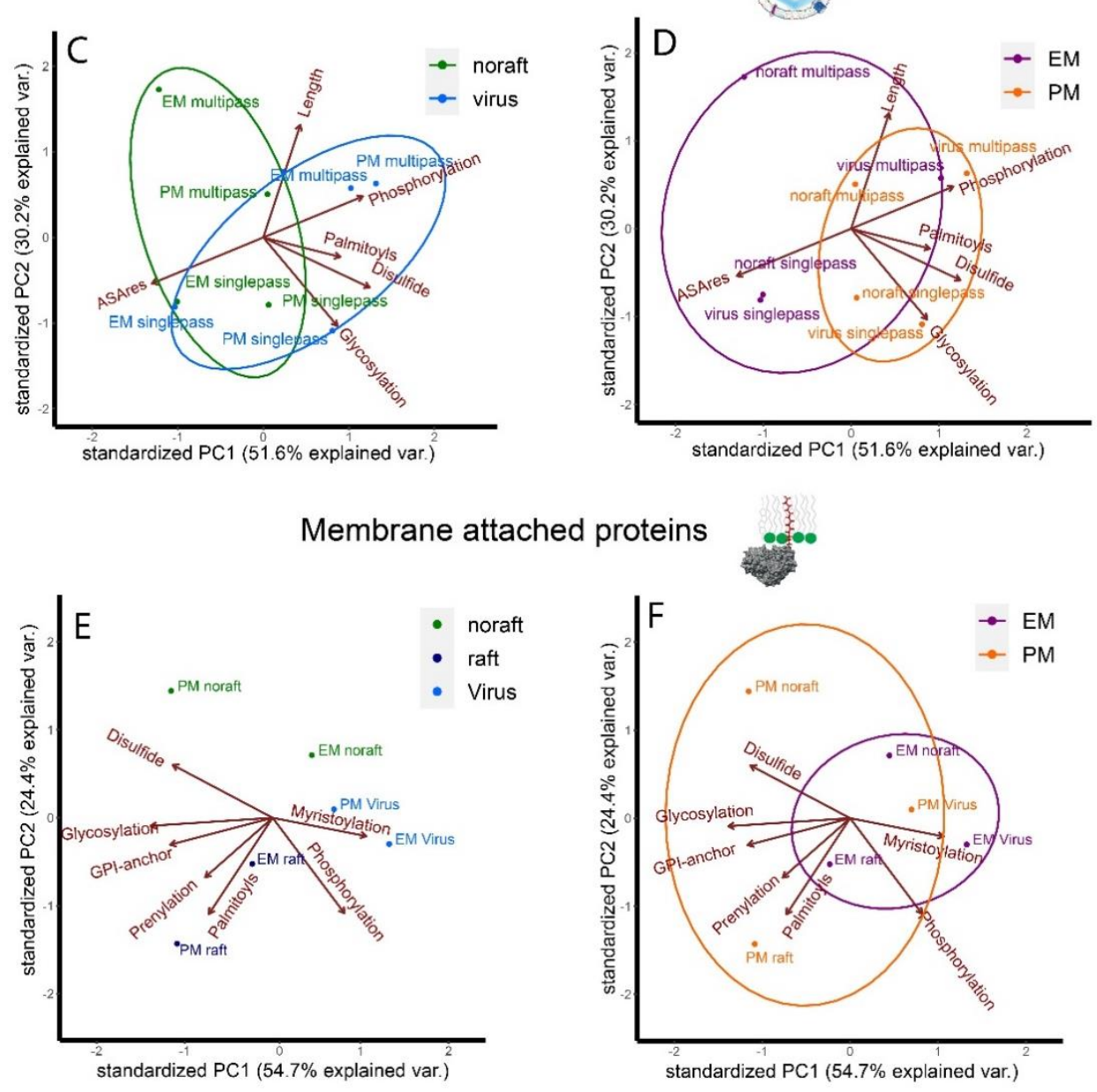

Figure S1 Principal component analysis on the fraction of modified proteins in transmembrane $(A, B, C, D)$ and attached membrane proteins $(E, F)$, in raft versus non-raft $(A, B)$ and virus versus nonraft $(C, D)$ proteins. After $P C A$, proteins are colored upon protein type in the left column (green=non raft, dark blue=raft and light blue=viral) or cellular localization in the right column (orange=plasma membrane and purple=endomembranes). 


\begin{tabular}{|c|c|c|c|c|}
\hline Param1 & Param2 & Pcoef & pvalue & Significance \\
\hline Fpalmitoyl & MVS & -0.96 & 0.0004879 & 1 \\
\hline Fphosphoryl & MVS & -0.58 & 0.1682139 & 0 \\
\hline Fglycosyl & MVS & -0.51 & 0.2448335 & 0 \\
\hline Fdisulfide & MVS & -0.86 & 0.0140998 & 1 \\
\hline Length & MVS & -0.11 & 0.8094234 & 0 \\
\hline ASAres & MVS & 0.28 & 0.543704 & 0 \\
\hline Fphosphoryl & Fpalmitoyl & 0.54 & 0.2111766 & 0 \\
\hline Fglycosyl & Fpalmitoyl & 0.67 & 0.1016425 & 0 \\
\hline Fdisulfide & Fpalmitoyl & 0.83 & 0.0207802 & 1 \\
\hline Length & Fpalmitoyl & -0.09 & 0.8484208 & 0 \\
\hline ASAres & Fpalmitoyl & -0.26 & 0.5660989 & 0 \\
\hline Fglycosyl & Fphosphoryl & 0.1 & 0.8257213 & 0 \\
\hline Fdisulfide & Fphosphoryl & 0.13 & 0.777667 & 0 \\
\hline Length & Fphosphoryl & -0.16 & 0.7250033 & 0 \\
\hline ASAres & Fphosphoryl & -0.47 & 0.2925557 & 0 \\
\hline Fdisulfide & Fglycosyl & 0.51 & 0.2437955 & 0 \\
\hline Length & Fglycosyl & -0.13 & 0.7833978 & 0 \\
\hline ASAres & Fglycosyl & 0.24 & 0.5979512 & 0 \\
\hline Length & Fdisulfide & 0.17 & 0.7086394 & 0 \\
\hline ASAres & Fdisulfide & 0.06 & 0.900748 & 0 \\
\hline ASAres & Length & 0.18 & 0.7015171 & 0 \\
\hline
\end{tabular}

Table S1 Correlation matrix of viral protein modifications corresponding to figure $6 \mathrm{~A}$ in manuscript 